\title{
UTILIZAÇÃO DE MODELOS DIDÁTICOS TATEÁVEIS COMO METODOLOGIA PARA O ENSINO DE BIOLOGIA CELULAR EM TURMAS INCLUSIVAS COM DEFICIENTES VISUAIS
}

\author{
Angela Michelotti ${ }^{1}$ \\ Elgion Lucio da Silva Loreto²
}

\begin{abstract}
RESUMO
O entendimento de estruturas celulares, pela natureza microscópica, exige elevado nível de abstração, e se torna um desafio aos alunos com e sem limitação visual. Metodologias alternativas podem proporcionar aos alunos visualizarem, manipularem, tocarem em modelos que representem as verdadeiras estruturas celulares, auxiliando assim o aprendizado. Neste estudo testamos a hipótese de que modelos tridimensionais de diversos tipos celulares, assim como de processos envolvendo células (multiplicação celular e a cicatrização), utilizados inicialmente de forma tátil, podem ser uma ferramenta eficiente para o ensino de biologia celular em uma perspectiva de inclusão de alunos com Necessidades Educativas Especiais (NEE). Participaram da atividade 23 alunos videntes e 5 com deficiência visual, de 8 ㅇ e 9 o anos do Ensino Fundamental, de duas escolas públicas do Rio Grande do Sul. Os resultados mostraram que a utilização de modelos didáticos tridimensionais, construídos de forma que fosse possível tateá-los, manipulá-los, pode contribuir para a inclusão de alunos com deficiência visual na classe regular de ensino, assim como tornar o ensino de biologia celular mais atrativo e dinâmico. Os alunos tiveram um bom aproveitamento em relação ao aprendizado relativo à diversidade das formas celulares e do papel das células nos processos de crescimento e cicatrização.
\end{abstract}

Palavras-chave: Deficiência visual. Modelos didáticos. Célula. Inclusão.

\section{USE OF TATTOOUS DIDACTIC MODELS AS METHODOLOGY FOR THE TEACHING OF CELLULAR BIOLOGY IN INCLUSIVE TOURS WITH VISUAL DISABILITIES}

\begin{abstract}
The understanding of cellular structures, due it microscopic nature, requires a high level of abstraction, and it becomes a challenge for students with and without visual limitation. Alternative methodologies can enable students to visualize, manipulate and touch on models that represent real cell structures, and thus improve the learning. In this study, we tested the hypothesis that three-dimensional models of several cell types, as well as the process involving cells (cell multiplication and healing), initially tactilely used, can be an efficient tool for the teaching of Cell Biology in a perspective of inclusion of pupils visually impaired. Participated of study 23 seers and 5 visually impaired students, 8 and 9 years of elementary school, from two public schools in Rio Grande do Sul - Brazil. The results showed that the use of three-dimensional didactic models, constructed in such a way as to be able to manipulate them, can contribute to the inclusion of students with visual impairment in the regular classroom, as well as make the teaching of cellular biology more attractive and dynamic. Seer students first and have made good use of learning about the diversity of cell forms and the role of cells in growth and healing processes.
\end{abstract}

Keywords: Visual deficiency. Didactic models. Cell. Inclusion.

Recebido em: 20/1/2019

Aceito em: 10/2/2019

\footnotetext{
${ }^{1}$ Graduação em Ciências Biológicas - Licenciatura Plena (Ulbra, 2011). Pós-Graduação em Educação Ambiental (UFSM, 2013). Mestrado em Educação em Ciências: Química da Vida e Saúde (UFSM). Doutoranda em Educação em Ciências: Química da Vida e Saúde (UFSM). http:// lattes.cnpq.br/6513790493603208. http://orcid.org/0000-0002-5445-7386. angela_michelotti@hotmail.com

${ }^{2}$ Doutorado e Mestrado em Genética e Biologia Molecular/UFRGS. Graduação em Ciências Biológicas (UFSM). Departamento de Bioquímica e Biologia Molecular CCNE (UFSM). http://lattes.cnpq.br/6493669115018157. http://orcid.org/0000-0002-7586-8168. elgion@base.ufsm.br
} 
O ensino de biologia celular, tanto para alunos com deficiência visual quanto para os que não apresentam deficiência, é marcado por diversas dificuldades, devido principalmente ao alto grau de abstração necessário para o entendimento das estruturas celulares. O caráter abstrato dessa área do conhecimento resulta da natureza microscópica de seu objeto de estudo, a células e suas estruturas, tornando a compreensão do funcionamento celular, e a apropriação do vocabulário próprio da área, um desafio.

Este trabalho é um recorte da dissertação de Mestrado da primeira autora, em que se buscou, com a utilização de modelos didáticos e de atividades de percepção tátil, integrar os alunos, com e sem deficiência visual, em uma atividade que estimulasse os sentidos dos participantes. Além disso, buscou-se demonstrar aos alunos sem deficiência visual o quão importante é a utilização do tato no dia a dia dos colegas com essa deficiência. A atividade foi pensada e planejada com o intuito de atender, em uma mesma atividade, todos os alunos videntes e com deficiência visual, sem segregar ou excluir nenhum deles.

A proposta de utilizar modelos didáticos tridimensionais táteis, feitos com biscuit, em uma atividade que integrasse os alunos com e sem deficiência visual, em duas escolas públicas do Rio Grande do Sul, teve como objetivo principal testar a hipótese de que a utilização desses modelos pode auxiliar alunos videntes e com deficiência visual no aprendizado de conceitos básicos de biologia celular. A pesquisa ocorreu em duas turmas distintas, uma de 8 o e outra de 90 ano do Ensino Fundamental. $O$ total de alunos participantes foi de 23 alunos videntes e 5 alunos com deficiência visual (três cegos e dois com baixa visão).

No decorrer do trabalho são apresentados a fundamentação teórica, logo em seguida são abordados os procedimentos metodológicos, resultados e discussões e a conclusão da pesquisa.

\section{FUNDAMENTAÇÃO TEÓRICA}

A inclusão é muito mais do que somente incluir um aluno na escola regular de ensino. Incluir o portador de Necessidades Educativas Especiais (NEE) proporciona-lhe uma relação de interação com outras pessoas, como colegas e professores, propicia-lhe conhecimento de um mundo a descobrir, cheio de obstáculos e informações para desvendar, possibilita-Ihe descobrir coisas que ele nem imaginava que poderia ser capaz de fazer.

Camargo (2016) defende a importância de práticas inclusivas, que sejam utilizadas por alunos com e sem deficiência no ambiente escolar, como a confeç̧ão e o uso de modelos didáticos como metodologia alternativa, enriquecendo o ensino e a aprendizagem, criando significados mais bem estruturados aos educandos, ao manipularem estes materiais.

As metodologias alternativas buscam promover um ensino significativo e abrangente às diferentes formas de aprender entre os educandos (PAULA; GUIMARÃES; SILVA, 2017). A utilização destas metodologias, em conjunto com a interação dos alunos com e sem deficiência visual, pode gerar uma melhor compreensão das temáticas abordadas e promover a convivência com o outro (VITALIANO; MANZINI, 2010). 
No que se refere ao desenvolvimento de atividades comuns aos alunos com e sem deficiência visual, os pesquisadores compreendem que é possível e fundamental tornar o ambiente de sala de aula acessível aos alunos cegos, com baixa visão, e videntes, propiciando, assim, um meio em que esses alunos possam dialogar sobre o mesmo assunto (PAULA; GUIMARÃES; SILVA, 2017, p. 869).

As atividades didáticas realizadas com o uso de modelos tridimensionais táteis podem ser uma alternativa metodológica para integrar alunos com NEE, principalmente os alunos com deficiência visual e os demais colegas, revelando-se também um facilitador de aprendizagem. "A diversidade não é somente valorizada, mas também deve ser considerada como um potencializador da união entre os membros de um grupo que favoreça a aprendizagem conjunta de todos os alunos" (LIPPE; CAMARGO, 2016, p. 56).

Giordan e Vecchi (1996, p. 195) enfatizam que: "o modelo é um sistema figurativo que reproduz a realidade de forma esquematizada e concreta tornando-o mais compreensível ao aluno". Já para Justina et. al. (2003, p. 137), o modelo "Representa uma estrutura que pode ser utilizada como referência, uma imagem que permite materializar a ideia ou conceito tornando-o dessa forma assimilável". Reis et al. (2013) apontam que o uso de modelos didáticos pode ser um recurso metodológico que facilita a aprendizagem e proporciona uma educação de qualidade.

Com o uso de modelos didáticos passíveis de serem manipulados, buscamos reproduzir estruturas celulares a serem estudadas nas aulas de Ciências, de forma projetada e concreta, tornando mais acessível a sua percepção por parte do aluno. Com o uso desses modelos didáticos conseguimos abordar o conteúdo para alunos videntes e para os não videntes.

Coimbra (2003, p. 53) ressalta que "a perda de um dos sentidos centrais não torna o indivíduo incapaz. Entretanto, torna-o imperfeito aos olhos da sociedade e, por isso, sujeito a atitudes preconceituosas e, eventualmente, segregacionistas ou restritivas à sua participação social". "Não se nega que, biologicamente, a cegueira é muito limitadora[...]. Porém, socialmente, ela não é limitadora, porque a pessoa com cegueira, pela palavra, pela comunicação com o outro, apropria-se do real ao internalizar os significados culturais" (CAIADO, 2014, p.43-44). Assim entendido, os alunos com deficiência visual podem ter a mesma aptidão intelectual e cognitiva, apresentando o mesmo potencial da aprendizagem dos demais alunos da classe, mediante estímulos e condições nos ambientes escolares adequados para tal deficiência.

Silva, Landim e Souza (2014) enfatizam a necessidade de utilizar materiais tateáveis com alunos com deficiência visual. Compete aos docentes organizarem o currículo com estratégias de ensino e metodologias apropriadas aos alunos portadores de NEE e, além disso, englobar os estudantes videntes nessas atividades, proporcionando a formação de cidadãos mais conscientes, tolerantes, sem preconceitos e que busquem ajudar o próximo, independentemente de suas deficiências.

O presente estudo busca testar a hipótese de que a utilização de modelos didáticos tridimensionais táteis pode auxiliar alunos videntes e com deficiência visual no aprendizado de conceitos básicos de biologia celular. 


\section{METODOLOGIA}

A pesquisa ocorreu em duas turmas distintas, uma de 8 ㅇ e outra de 90 ano do Ensino Fundamental, em escolas públicas no Estado do Rio Grande do Sul. A duração da atividade foi de 6 horas/aulas em cada turma. Na turma de 8 ano o número de participantes foi de 15 alunos videntes e 4 com deficiência visual (dois cegos e dois com baixa visão). Na turma de 9 o foram 8 alunos videntes e 1 aluno com deficiência visual (cego). 0 total de participantes foi de 23 alunos videntes e 5 com deficiência visual (três cegos e dois com baixa visão).

Em um primeiro momento solicitou-se aos alunos o preenchimento de um questionário aberto contendo quatro questões descritivas (na primeira questão solicitou-se que a resposta ocorresse a partir da elaboração de uma ilustração). Os alunos com deficiência visual receberam o questionário adaptado. Para dois alunos cegos da turma do 8 ano foi transcrito no Dosvox (Sistema computacional que se comunica com o usuário pelo uso da síntese de voz, viabilizando o uso de computadores para deficientes visuais); para um aluno cego do 9o ano o questionário foi impresso em braile, e para os dois alunos com baixa visão foram impressos com letras ampliadas. Os alunos que utilizaram o programa Dosvox preferiram descrever a questão 1 , na qual foi solicitada a ilustração. O questionário abordou assuntos como conceito/imagem de células, formatos das células, crescimento humano e processo de cicatrização da pele. As questões dos questionários são descritas na seção de resultados.

A atividade subsequente foi pensada e elaborada para que pudesse envolver todos os alunos, videntes e não videntes, propondo-se às turmas uma sequência de percepção tátil com modelos didáticos tridimensionais de células. Estes modelos foram confeccionados pelos pesquisadores com massa de "biscuit". A escolha da massa de "biscuit" deveu-se ao fato de ser de fácil manuseio e ter boa durabilidade (MATOS et al., 2009). Os modelos tridimensionais apresentam formas e tamanhos variados conforme as características das respectivas células escolhidas. Na Figura 1 podem ser visualizados os modelos celulares didáticos confeccionados.

Figura 1 - Modelos didáticos tridimensionais de células

\begin{tabular}{|c|c|c|c|c|}
\hline Célula Muscular & Neurônio & Hemácia & Plaqueta & Célula Epitelial \\
\hline & & & & \\
\hline & & & & \\
\hline
\end{tabular}

Fonte: Os autores.

Dentro dos conteúdos relacionados às células, optamos por conceitos mais gerais e concretos, como crescimento, cicatrização e diferenciação celular em detrimento das estruturas subcelulares. Estas últimas são pouco significativas nessa fase do ensino, enquanto os primeiros são fundamentais (CARLAN et al., 2014). Esses autores salientam que, no Ensino Fundamental, devemos centrar esforços em trabalhar os conceitos mais gerais e fáceis de relacionar aos fenômenos do cotidiano dos alunos. 
Foram confeccionados outros dois modelos didáticos, um o esquema embriológico das primeiras fases da formação de mórula e o outro representando as etapas da cicatrização da pele (Figura 2). Estes modelos tiveram como intuito facilitar a compreensão do processo de multiplicação celular e cicatrização da pele.

Figura 2 - Modelos didáticos tridimensionais: esquema embriológico das primeiras fases da formação de mórula (esquerda) e esquema das etapas da cicatrização da pele (direita)

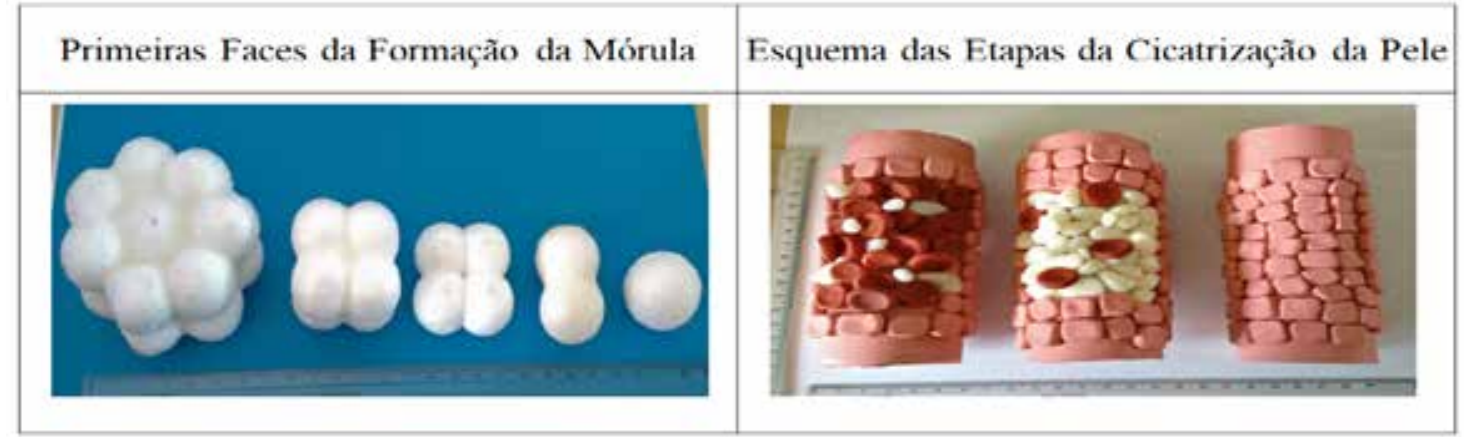

Fonte: Os autores.

Para a realização da atividade de percepção tátil foram confeccionadas cinco caixas adaptadas pare este fim. Estas caixas, de plástico preto, possuíam duas aberturas, revestidas com tecido, com os alunos podendo colocar as mãos dentro da caixa sem enxergar o que estavam manuseando. A atividade ocorreu do seguinte modo: primeiramente, os modelos tridimensionais do formato das células foram colocados individualmente nas caixas de percepção tátil. Os alunos não tiveram contato com esses modelos antes da atividade tátil.

As caixas de percepção tátil foram colocadas lado a lado, sobre mesas da sala de aula, conforme a Figura 3:

Figura 3 - Realização da atividade de percepção tátil com os alunos participantes

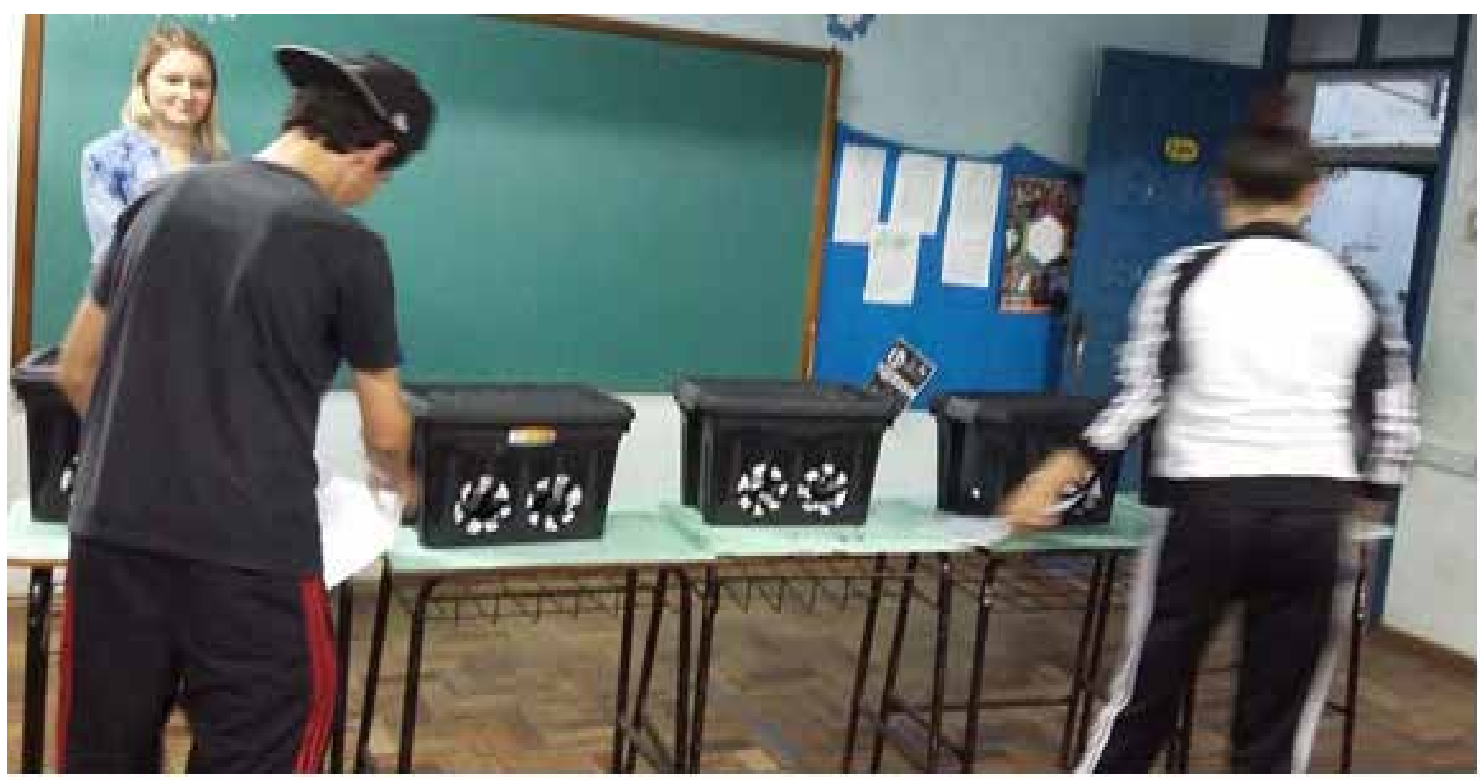

Fonte: Os autores. 
Na sequência os alunos foram chamados individualmente para realizarem a atividade de percepção tátil. Eles foram orientados a não fazerem comentários durante a atividade. Os alunos com deficiência visual seguiram a rotina normal das atividades, juntamente como os demais. Após todos realizarem a atividade tátil, a pesquisadora retirou os modelos didáticos das caixas para os alunos visualizarem, manipularem, tocarem, e assim conhecerem detalhes das estruturas celulares representadas na forma de modelos didáticos. Logo após foi promovida uma sucinta discussão sobre as percepções dos alunos em relação à atividade de percepção tátil realizada.

$\mathrm{Na}$ aula subsequente a pesquisadora retornou à turma com os modelos didáticos e conversou com os alunos, informando a função das respectivas células, dando ênfase aos processos de embriologia, crescimento e cicatrização da pele, ocasião em que os modelos didáticos tridimensionais da Figura 2 também foram utilizados. Esses modelos serviram para auxiliar no momento da explicação e facilitar o entendimento dos processos explanados, constatando-se que os alunos com deficiência visual puderam tatear os modelos didáticos e ouvir a explicação dos respectivos processos, e os alunos videntes visualizaram de forma "ampliada" representações de tais processos.

Após duas semanas da realização das atividades, a pesquisadora retornou às turmas e solicitou aos alunos que respondessem o pós-teste I- um questionário com quatro questões (uma questão ilustrativa e três descritivas) que abordaram os mesmos tópicos do questionário realizado no início da atividade.

Cinco meses após a conclusão das atividades os alunos foram procurados e entrevistados. Durante a entrevista buscamos questionar os educandos sobre o que eles recordavam da atividade realizada, por exemplo, o nome e formato das células, como ocorre o processo de crescimento e de cicatrização, conceitos esses desenvolvidos e trabalhados com a apresentação dos modelos didáticos tridimensionais.

Optamos por realizar o pós-teste em duas etapas, duas semanas e cinco meses após a atividade prática, para avaliar se com a atividade de percepção tátil e a utilização dos modelos didáticos foi possível gerar uma aprendizagem efetiva e duradoura, permanecendo na memória dos alunos conceitos básicos de biologia celular. Conforme Arend e Del Pino (2017) demonstram em seu estudo, a utilização de pré e pós-teste é:

uma ferramenta adequada tanto para o ensino quanto para a aprendizagem em Biologia/Ciências, podendo aprimorar avaliações e acompanhamentos, tanto da validade de uma atividade proposta pelo professor quanto do desempenho do aluno; comprovando ou refutando hipóteses propostas pelo professor pesquisador; promover comparações entre grupos de alunos, dentro de um planejamento ao nível de série, grupos de disciplina (Ciências Exatas e da Natureza, por exemplo) (AREND; DEL PINO, 2017, p. 85).

\section{RESULTADOS}

Para verificar quais eram os conhecimentos prévios dos 23 alunos videntes e dos cinco com deficiência visual sobre conceito/imagem de células, formatos das células, crescimento humano e processo de cicatrização da pele, foi aplicado um questionário inicial, contendo uma pergunta a ser respondida com um desenho e três perguntas dissertativas, descritas na Tabela 1 a seguir. 
Tabela 1 - Perguntas utilizadas nos questionários do pré-teste e pós-teste

PERGUNTA 1: "Quando o seu professor faz um comentário para a turma envolvendo o assunto 'célula': Qual a primeira imagem que vem na sua mente? Faça um desenho para representar".

PERGUNTA 2: "Todas as células têm formato da célula que você desenhou ou existem células que têm outros formatos"?

PERGUNTA 3: "Do nascimento até nos tornarmos adultos, todos nós crescemos. Você acha que as células têm algum papel no nosso crescimento? Se você acha que sim, explique que papel seria este".

PERGUNTA 4: "Quando nos cortamos, logo após surge uma 'casquinha' e ocorre a cicatrização. As células desempenham algum papel no processo de cicatrização? Se você acha que sim, explique que papel seria este".

Elaboração: Os autores.

Na pergunta 1, 16 alunos videntes representaram a célula com o tradicional desenho do "ovo frito" (Figura 4), no qual podemos perceber claramente as três estruturas principais (núcleo, citoplasma e membrana plasmática), representadas por dois círculos, colocando-se um no interior do outro, lembrando um "ovo frito". Destes alunos, três completaram a imagem denominando as partes corretamente (Figura $4-A$ ), um dos participantes associou a palavra célula com a ilustração de um microscópio (Figura $4-B$ ), dois ilustraram uma hemácia (Figura $4-C$ ), dois alunos representaram a célula como parte integrante do ser humano (Figura 4-D), um enfatizou que a célula é parte integrante do corpo humano, sendo encontrada nos vasos sanguíneos (Figura $4-E$ ), e um representou a célula com figuras que os pesquisadores não conseguiram interpretar (Figura 4-F).

Na percepção dos alunos com deficiência visual, um aluno com baixa visão representou o processo de divisão celular como a descrição: "a professora desenhou uma vez no quadro este processo" (Figura 4-G), um aluno com baixa visão desenhou um círculo com as três divisões - cortes vertical e horizontal, um dos alunos cegos fez o desenho e ilustrou o formato da célula "ovo frito". Este aluno realizou a sua ilustração utilizando a punção para escrita em braile e um pedaço de folha de EVA, colocando a folha do questionário em cima da folha de EVA e demarcou os pontos sobre (Figura $4-\mathrm{H}$ ). Dois alunos cegos preferiram descrever como imaginavam a célula ao invés de ilustrar: "Pequenas coisas redondas superminúsculas, de diferentes tamanhos, mas todas pequenas. A cor, eu não consigo imaginar, mas provavelmente deve ser branca"; "A primeira imagem que vem a minha mente é de vários tubos pequenos com três partes principais trabalhando entre si para fazer o funcionamento do corpo". 
Figura 4 - Desenhos realizados pelos alunos na primeira questão do questionário

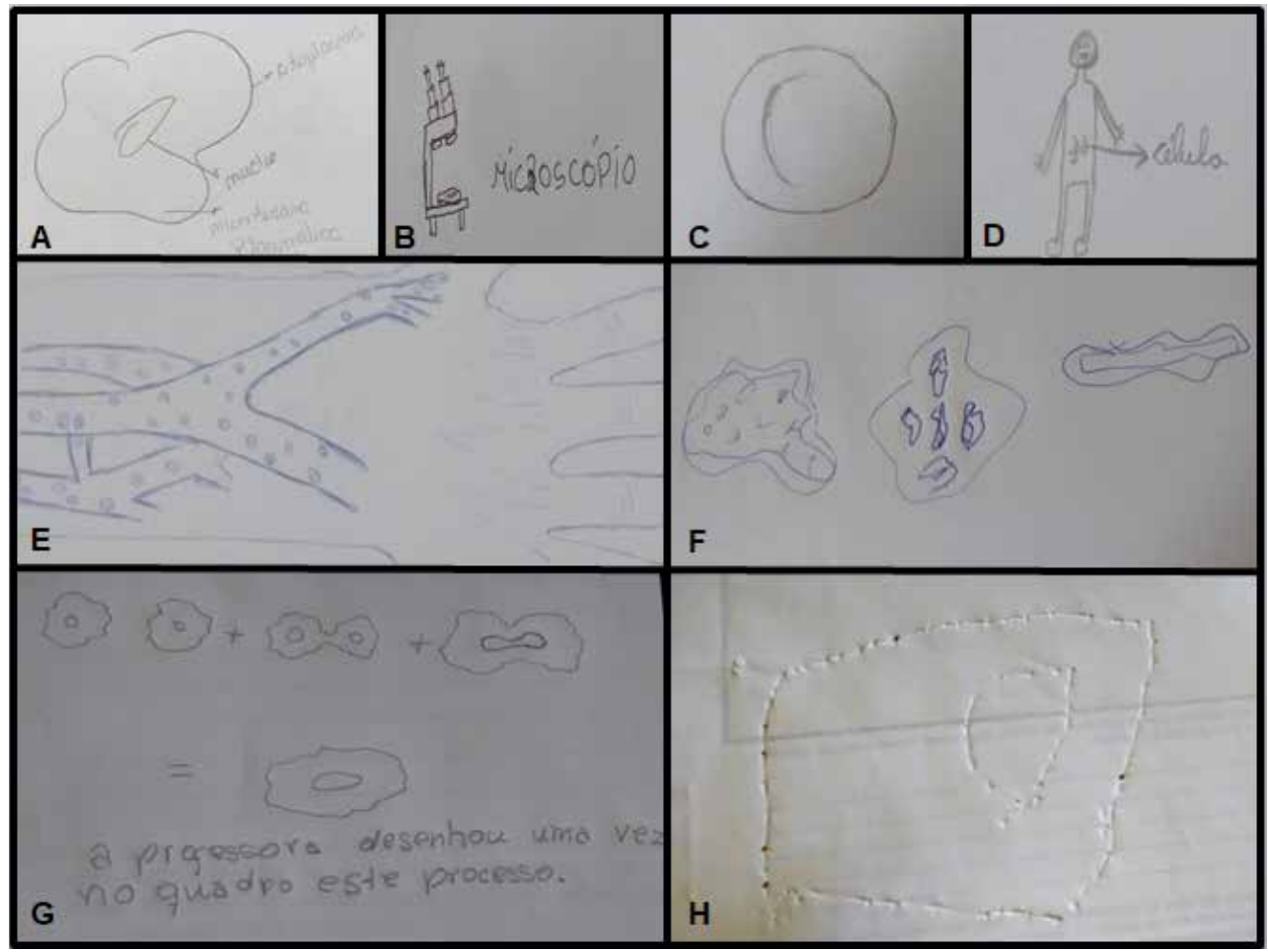

(A) célula modelo "ovo frito" com suas denominações; (B) célula no microscópio; (C) hemácia; (D) célula como parte integrante do ser humano; (E) presença de células nos vasos sanguíneos de uma mão; (F) imagem sem interpretação; (G) divisão celular - imagem desenhada pela aluna com baixa visão; $(H)$ célula modelo "ovo frito" desenhada por aluno deficiente visual, com a punção e EVA.

Fonte: Os autores.

Nas perguntas dissertativas os assuntos abordados foram formatos das células, crescimento humano e processo de cicatrização, respectivamente, nas perguntas 2, 3 e 4.

Na pergunta 2, sobre o formato das células (Figura 5), 16 alunos videntes relataram que as células têm formatos diferentes, 7 alunos afirmaram que todas as células têm o mesmo formato do ilustrado na pergunta anterior. Dos alunos com deficiência visual, 3 afirmaram que as células têm formatos diferentes e 1 relatou que as células têm o mesmo formato e, por fim, 1 não soube responder.

Figura 5 - Resultados obtidos nas respostas da segunda questão: "Todas as células têm o formato da célula que você desenhou ou existem células que têm outros formatos?"

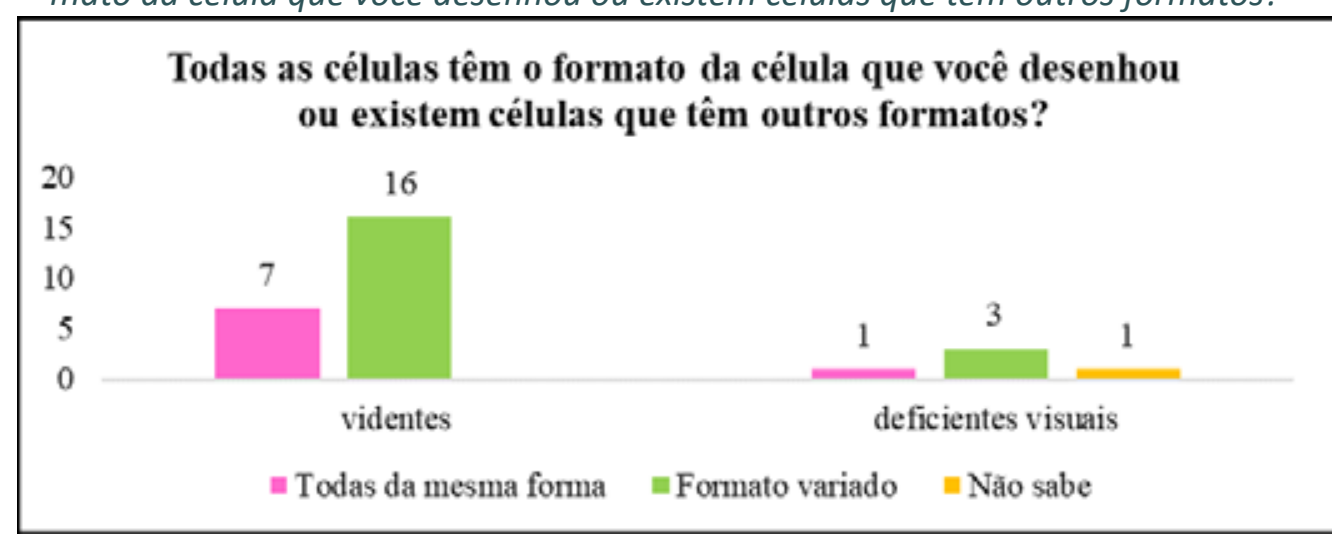

Fonte: Os autores. 
$\mathrm{Na}$ terceira pergunta, que abordava o assunto crescimento humano, 17 alunos videntes descreveram que a célula faz parte do desenvolvimento do corpo humano e ajuda na formação/crescimento do indivíduo (Figura 6), 1 aluno relacionou o crescimento do ser humano com o processo de cicatrização, 1 fez um breve relato dando a ideia de que a célula se multiplica, originando novas células, e outro aluno deu a entender que as células aumentam de tamanho, conforme crescemos. Três não lembraram ou não souberam responder, 1 argumentou que a célula não tem papel no nosso crescimento, com o seguinte relato: "Eu acho que não, por que não tem nada a ver o nosso crescimento com as células, elas não apresentam nenhum papel nessa função". Já 3 alunos com deficiência visual afirmaram que a célula faz parte do desenvolvimento do corpo humano e ajuda na formação/crescimento do indivíduo, 1 aluno relacionou o crescimento do ser humano com o processo de cicatrização e 1 respondeu que acredita que as células têm relação com nosso crescimento, mas, na sua justificativa, argumentou erroneamente, frisando que as células aumentam de tamanho conforme crescemos. Segue a sua afirmação: "Acho que sim. Acho que quando somos muito pequenos, as células devem ser tão pequenas que podem ser vistas com microscópio. E quanto mais crescemos, maior elas ficam".

Figura 6 - Resultados obtidos nas respostas da terceira questão: "Do nascimento até nos tornarmos adultos, todos nós crescemos. Você acha que as células têm algum papel no nosso crescimento? Se você acha que sim, explique que papel seria este"

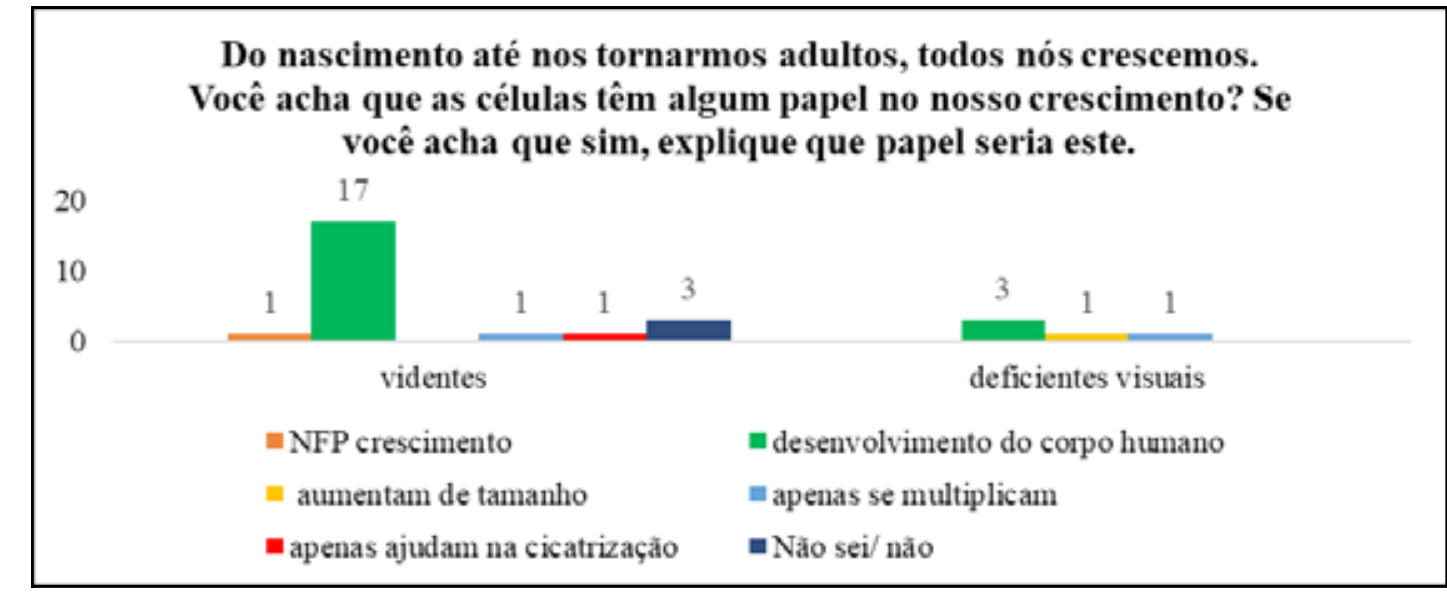

* NFP (não faz parte)

Fonte: Os autores.

Por fim, na pergunta 4, que trata do processo de cicatrização (Figura 7), 18 alunos videntes afirmaram que as células participam no processo de cicatrização e 5 tiveram dúvidas ou não responderam à questão. $O$ aluno vidente que respondeu à pergunta 3 afirmando que as células não têm papel no nosso crescimento, agora argumentou que elas desempenham um papel no processo de cicatrização, com a seguinte fala: "Sim, porque as células cicatrizam os machucados criando pele novamente. Então, por isso que surgem as casquinhas." Já 3 alunos com deficiência visual relataram que as células participam do processo de cicatrização e 2 não souberam responder. 
Figura 7 - Resultados obtidos nas respostas da quarta questão: "Quando nos cortamos, logo após surge uma 'casquinha' e ocorre a cicatrização. As células desempenham algum papel no processo de cicatrização? Se você acha que sim, explique que papel seria este."

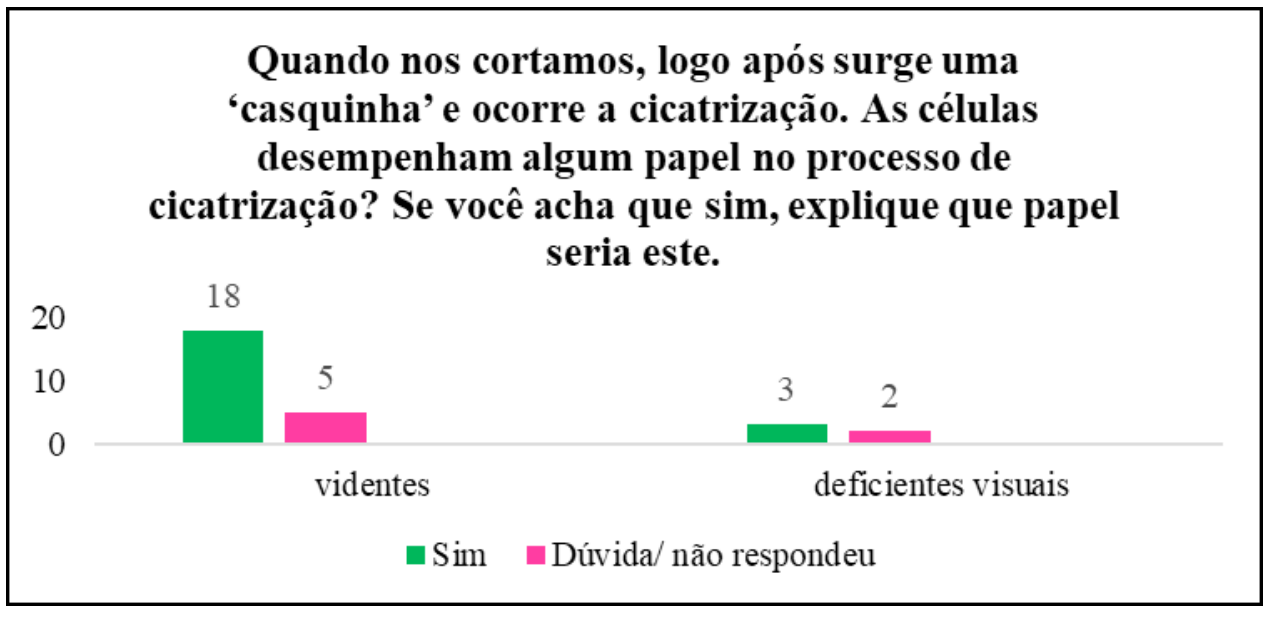

Fonte: Os autores.

\section{Atividade Percepção Tátil}

A atividade de percepção tátil foi pensada e proposta aos alunos com o intuito de os alunos videntes estimularem os seus sentidos e poderem perceber como é o dia a dia dos colegas com deficiência visual. A atividade também objetivou atingir todos os alunos, videntes e com deficiência visual, sem segregar ou excluir nenhum aluno da atividade. As caixas táteis foram colocadas sobre mesas escolares, na sala de aula (Figura 3). Os alunos foram chamados individualmente para que realizassem a atividade. Foi solicitado aos participantes que não tivessem interação durante a atividade, para que não interferisse nas suas percepções. A atividade consistia em desenhar e/ou descrever o que estavam tateando no interior das caixas. Com a atividade, percebemos que os alunos, ao utilizar o sentido tátil, conseguiram interpretar a forma dos modelos celulares, puderam descrever ou desenhar, mas tiveram grande dificuldade para interpretar as estruturas no contexto da biologia celular. Na descrição dos modelos didáticos, na atividade tátil, os alunos fizeram comparações com objetos que eles manuseiam e/ou enxergam, e estão presentes no seu cotidiano, como: célula sanguínea parece com um pratinho, célula muscular, parece com uma folha, um olho, a célula epitelial parece com uma borracha, a plaqueta, com uma batata, já na célula nervosa não houve comparações com objetos do dia a dia. Os resultados obtidos na atividade de percepção tátil são sumarizados na Tabela 2. 
Tabela 2 - Resultados obtidos a partir da atividade tátil dos alunos videntes e com deficiência visual

VIDENTES DEFICIENTES VISUAIS

\begin{tabular}{|c|c|c|}
\hline \multirow{3}{*}{$\begin{array}{l}\text { CAIXA1: modelo } \\
\text { didático da célulc } \\
\text { nervosa }\end{array}$} & $\begin{array}{l}16 \text { conseguiram ilustrar a forma do neurônio, } \\
\text { o mas sem relacionar com a célula nervosa } \\
\text { la }\end{array}$ & $\begin{array}{c}1 \text { realizou o desenho, sem relacionar com a } \\
\text { célula nervosa }\end{array}$ \\
\hline & $\begin{array}{c}3 \text { realizaram a representação e relacionaram } \\
\text { com a célula nervosa. }\end{array}$ & \multirow[t]{2}{*}{4 realizaram a descrição da célula tateada } \\
\hline & quatro apenas descreveram a forma tateada & \\
\hline \multirow{3}{*}{$\begin{array}{l}\text { CAIXA 2: modelo } \\
\text { didático da célula } \\
\text { sanguínea - } \\
\text { hemácia }\end{array}$} & $\begin{array}{l}23 \text { descreveram a forma, sem relacionar com a } \\
\text { célula sanguínea. Destes: }\end{array}$ & a 3 descreveram a forma da célula tateada \\
\hline & $\begin{array}{c}3 \text { compararam com "um prato", ou "uma } \\
\text { tigela", ou "um núcleo" }\end{array}$ & $\begin{array}{c}1 \text { descreveu a forma e comparou com "um } \\
\text { pratinho". }\end{array}$ \\
\hline & 1 dos alunos comparou com a célula animal & 1 apenas ilustrou a célula tateada \\
\hline \multirow[t]{3}{*}{$\begin{array}{l}\text { CAIXA 3: modelo } \\
\text { didático da célulc } \\
\text { muscular }\end{array}$} & $\begin{array}{l}\text { lo } 23 \text { descreveram e/ou desenharam a forma, } \\
\text { la mas sem relacionar com a célula muscular. } \\
\text { Destes: }\end{array}$ & 3 realizaram a descrição da célula tateada \\
\hline & $\begin{array}{c}3 \text { compararam a estrutura com alguma parte } \\
\text { de um vegetal, como por exemplo: "folha de } \\
\text { babosa", "folha de laranjeira - célula vegetal", } \\
\text { "algo de uma planta" }\end{array}$ & 1 realizou a ilustração da célula tateada \\
\hline & 1 referiu-se como se fosse "um olho" & $\begin{array}{l}1 \text { descreveu a forma tateada e comparou-a com } \\
\text { "um disco de jogar" }\end{array}$ \\
\hline \multirow{4}{*}{$\begin{array}{l}\text { CAIXA 4: célula } \\
\text { epitelial }\end{array}$} & $\begin{array}{l}16 \text { descreveram a célula tateada, sem } \\
\text { relacionar com a célula epitelial }\end{array}$ & $\begin{array}{c}3 \text { realizaram apenas a descrição da célula } \\
\text { tateada. }\end{array}$ \\
\hline & $\begin{array}{c}2 \text { descreveram a célula tateada de forma que } \\
\text { não condizia com o modelo didático } \\
\text { apresentado }\end{array}$ & 1 realizou a ilustração da célula tateada \\
\hline & $\begin{array}{c}4 \text { realizaram comparações, como "formato de } \\
\text { picolé", "formato de uma borracha", "formato } \\
\text { de um paralelepípedo com curvas, não conheço } \\
\text { nenhuma célula com tal formato" }\end{array}$ & \multirow{2}{*}{$\begin{array}{c}1 \text { descreveu a forma realizando comparações } \\
\text { com "um chiclete grande ou uma barra de } \\
\text { chocolate". }\end{array}$} \\
\hline & $\begin{array}{l}1 \text { comparou a célula tateada com a célula } \\
\text { vegetal }\end{array}$ & \\
\hline \multirow{5}{*}{$\begin{array}{l}\text { CAIXA 5: célula } \\
\text { sanguínea - } \\
\text { plaqueta }\end{array}$} & 15 realizaram ilustração da célula. & \multirow[b]{2}{*}{3 realizaram a descrição do modelo tateado } \\
\hline & $\begin{array}{l}3 \text { realizaram a descrição da célula tateada, } \\
\text { compararam tal estrutura com "uma pera" }\end{array}$ & \\
\hline & $\begin{array}{l}2 \text { realizaram a descricão da célula tateada e } \\
\text { compararam com uma "pedra" }\end{array}$ & \multirow{2}{*}{1 comparou com "uma batata" } \\
\hline & $\begin{array}{l}2 \text { dois realizaram a descricão da célula tateada } \\
\text { e compararam com uma "gota d'água" }\end{array}$ & \\
\hline & $\begin{array}{l}1 \text { realiznı a decrrirãn da rélıla tateada e } \\
\text { comparou com um "funil deformado" }\end{array}$ & 1 comparou com "uma borracha". \\
\hline
\end{tabular}

Fonte: Os autores.

A atividade de percepção tátil foi realizada por alunos videntes e com deficiência visual (Figura 8). O intuito da atividade foi possibilitar que todos os alunos realizassem a mesma atividade, motivando os videntes para a utilização do tato como primeiro sentido da percepção dos formatos celulares, assim como proporcionando aos alunos com deficiência visual conhecer as células em 3D, facilitando a sua compreensão e a assimilação de suas formas. 
Figura 8 - Algumas imagens durante a atividade de percepção tátil

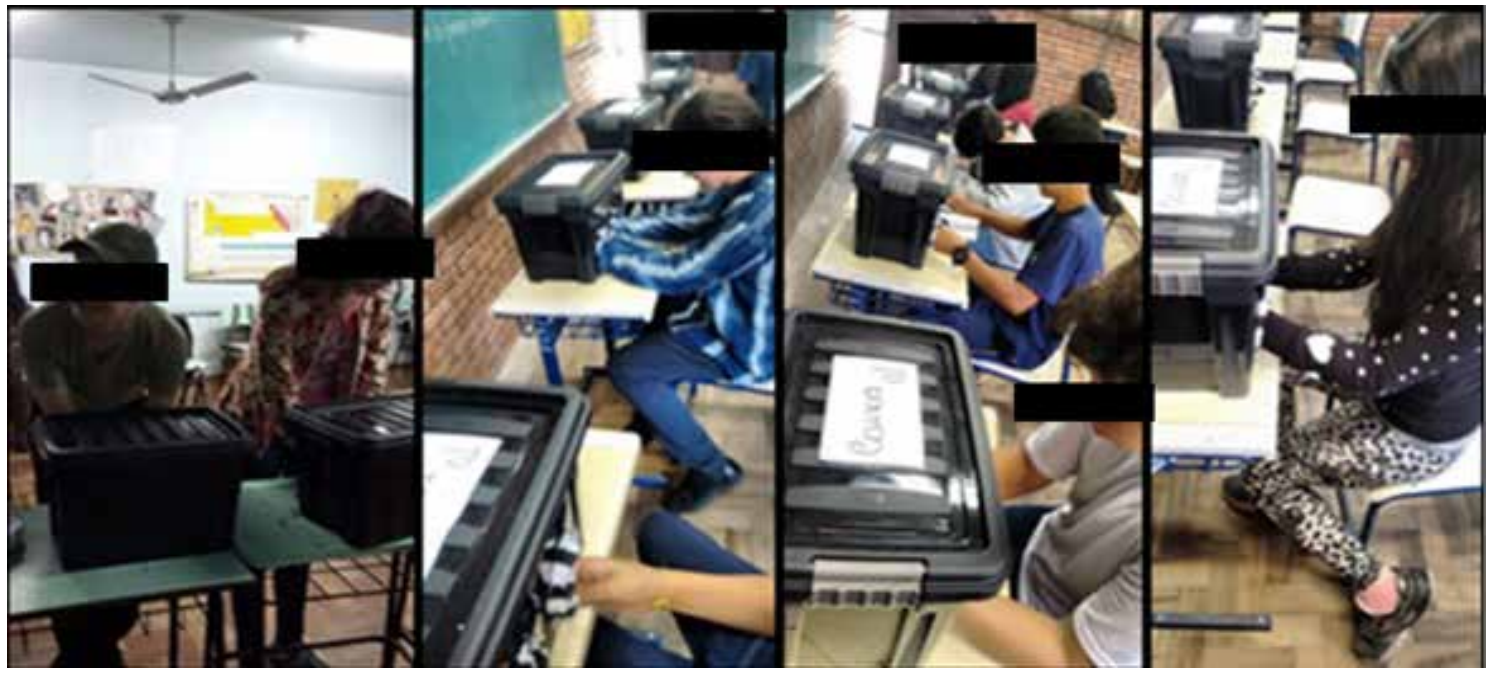

Fonte: Os autores.

\section{Pós-teste I}

A realização do pós-teste I ocorreu 15 dias após a realização das atividades de percepção tátil e da discussão sobre os conceitos e funções celulares. O pós-teste I foi realizado com 22 alunos videntes e com 5 com deficiência visual que estavam presentes no dia do teste.

Foram obtidos os seguintes resultados: na primeira questão (Figura 9), que se referia à descrição/ilustração do formato das células, 14 dos alunos videntes permaneceram com a imagem representativa da célula sendo o "ovo frito". Entre eles, 3 alunos apresentaram as denominações das três partes principais da célula (membrana plasmática, citoplasma e núcleo) (Figura 9-A), 3 desenharam a célula nervosa (Figura 9-C), 2 ilustraram uma hemácia (Figura 9 - F), 1 aluno representou a célula muscular (Figura 9 - B), 1 aluno representou o punho/mão com o sistema circulatório, com células (hemácias) nos vasos sanguíneos, célula epitelial, e representada nos dedos, e ainda as outras células trabalhadas na atividade ao redor da mão (Figura 9-E), 1 aluno representou novamente a célula com figuras que os pesquisadores não conseguiram interpretar (Figura $9-\mathrm{D})$.

Entre os alunos com deficiência visual, 3 representaram a tradicional imagem do "ovo frito", 1 aluno enfatizou, por meio da escrita, que imagina muitos círculos pequenos, e 1 aluno relatou que depende da célula, por exemplo, "a célula da pele faz lembrar o formato de um sabão". 
Figura 9 - Desenhos realizados pelos alunos

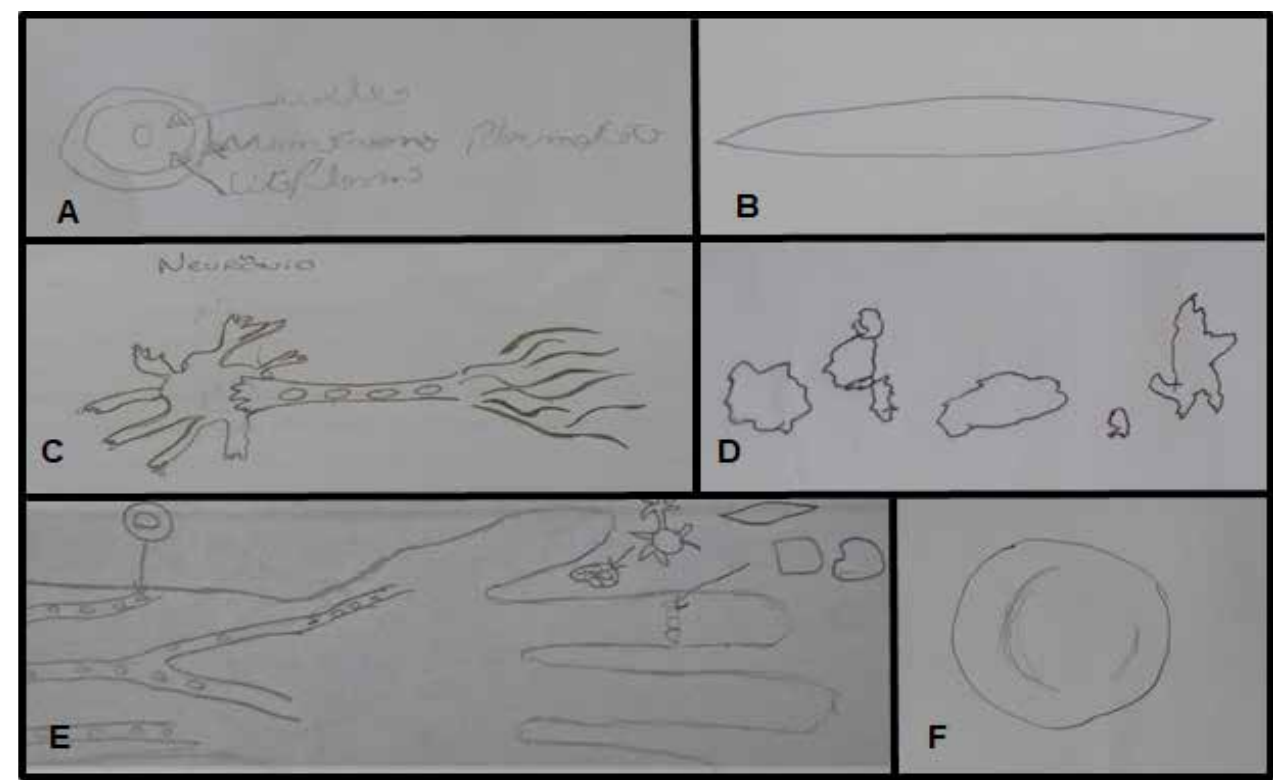

(A) célula modelo "ovo frito" com as suas denominações; (B) célula muscular; (C) célula nervosa; (D) imagem sem interpretação; (E) desenho de uma mão com vasos sanguíneos e, no interior, hemácias, células epiteliais na ponta do dedo indicador, além de célula nervosa, células musculares e outras ao redor da mão; (F) hemácia.

Fonte: Os autores.

No que se refere à questão 2 (Figura 10), que tratava sobre o formato que as células possuem, todos os 22 alunos videntes e os 4 com deficiência visual responderam que as células possuem formatos diferentes; um dos alunos com deficiência visual respondeu que têm o mesmo formato, este o mesmo que relatou na questão anterior que imagina as células como "pequenos círculos".

Figura 10 - Resultados obtidos nas respostas da segunda questão: "Todas as células têm o formato da célula que você desenhou ou existem células que têm outros formatos?"

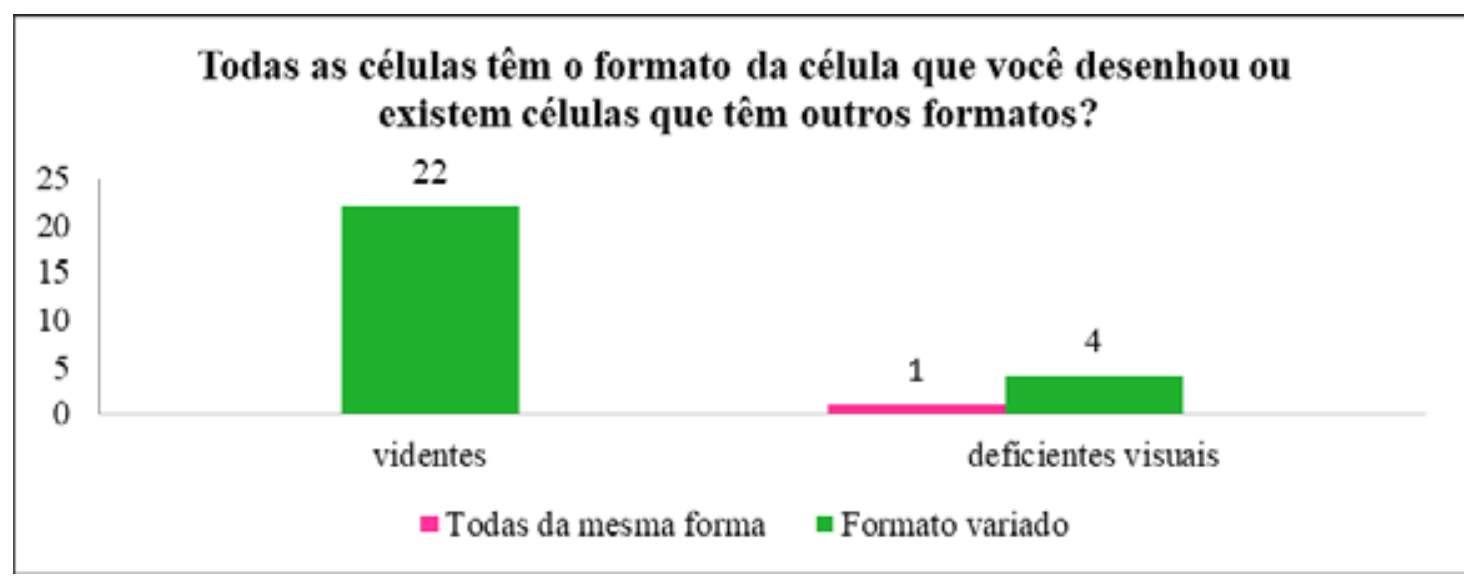

Fonte: Os autores.

Quanto à questão 3, que tratava sobre o papel desempenhado pelas células no crescimento, 21 dos alunos videntes afirmaram que as células atuam nesse processo e são parte fundamental para o nosso crescimento e desenvolvimento. Destes, 7 alunos explicaram em suas respostas que há crescimento quando há multiplicação celular; 1 aluno vidente não soube responder, deixando a questão sem resposta. Todos os 5 alu- 
nos com deficiência visual afirmaram que as células atuam no processo de crescimento e são parte fundamental para o nosso crescimento e desenvolvimento. Os alunos com deficiência visual fizeram outras considerações nas suas respostas dessa questão: 1 conseguiu relatar que o princípio do crescimento humano é o mesmo utilizado no processo de cicatrização da pele, 3 relataram que há crescimento humano quando há multiplicação celular.

Na questão 4, que abordava se as células participam do processo de cicatrização, os 22 alunos videntes e os 5 com deficiência visual responderam que as células atuam no processo de cicatrização. E, em suas respostas, alguns alunos ainda destacaram pontos importantes. Entre os videntes, 9 alunos relataram a importância de as células ajudarem no processo de cicatrização do ferimento, 5 souberam explicar o processo de cicatrização da pele de forma simples e 3 não souberam explicar o processo; outros 5 fizeram breves relatos em suas respostas que continham etapas da coagulação sanguínea, regeneração da pele, explicaram que a casquinha serve como proteção, etc.

Já entre os alunos com deficiência visual, 4 explicaram o processo de cicatrização da pele de forma simples e 1 aluno relatou que as células ajudam no processo de cicatrização do ferimento.

\section{Pós-teste II - Entrevista feita após cinco meses da realização da atividade}

Cinco meses após a realização das atividades, foi possível contatar 23 alunos videntes e quatro alunos com deficiência visual. Questionados oralmente sobre o que recordavam da atividade realizada anteriormente, todos os alunos participantes do pós-teste II argumentaram que as células apresentam formatos diferentes umas das outras, chegando até mesmo citar as formas celulares trabalhadas na atividade realizada. Sobre os temas de crescimento e processo de cicatrização da pele, todos os 23 alunos videntes e os 4 alunos com deficiência visual relataram que as células participam de ambos os processos. Alguns alunos, porém, argumentaram outras informações relevantes sobre os processos, 18 dos alunos videntes explicaram que o crescimento humano acontece quando há multiplicação celular, 5 não recordavam como ocorria o nosso crescimento, ainda que tenham relatado que as células estavam presentes nesse processo. Entre os alunos com deficiência visual, 3 afirmaram que as células atuam no processo de crescimento realizando a multiplicação celular e 1 não recordou, mas estava ciente de que as células participam no processo.

Quanto ao processo de cicatrização da pele, todos os 23 alunos videntes e quatro alunos com deficiência visual argumentaram que as células atuam nesse processo. Alguns ainda apresentaram outras informações importantes. Entre os alunos videntes, 19 souberam explicar o processo de cicatrização da pele de forma simples e sem citar nomes de células específicas que atuam no processo, 2 disserem que as células ajudam no processo de cicatrização da pele. Já entre os alunos com deficiência visual, 2 mencionaram que o papel das células no processo de cicatrização da pele seria o de multiplicação celular para fechar o corte, sem citar as etapas anteriores, 1 referiu que as células atuam em parte do processo de cicatrização da pele, ajudando na etapa de coagulação sanguínea e 1 não soube explicar o papel das células nesse processo. 
Os alunos entrevistados mencionaram, no final da entrevista, a relevância da atividade realizada com relação à interação entre os colegas e à importância do acesso ao conteúdo pelos seus colegas com deficiência visual.

\section{DISCUSSÃO}

Podemos encontrar vários trabalhos na literatura que apresentam vários benefícios decorrentes da utilização de modelos didáticos, principalmente os tridimensionais, no processo de ensino-aprendizagem. Por exemplo, esclarecem que os modelos possibilitam que o aluno construa o seu conhecimento e não apenas receba as informações teóricas, tornando as aulas mais dinâmicas e produtivas, facilitando o aprendizado (MATOS et al., 2009); permitem a materialização de uma ideia e/ou conceito, tornando mais assimilável (GIORDAN; VECCHI, 1996); viabilizam a experimentação e "possibilitam a compreensão dos conceitos, o desenvolvimentos das habilidades, competências e atitudes" (CAVALCANTE; SILVA, 2008, p. 1).

Nery e Rodriguez (1998) afirmam que a utilização de modelos didáticos facilita a compreensão e o aprendizado de processos biológicos, estimulando a curiosidade e a participação efetiva dos alunos. Já Orlando et al. (2009, p. 2) destacam que “(...) do lado visual, esses modelos permitem que o estudante manipule o material, visualizando-o de vários ângulos, melhorando, assim, sua compreensão sobre o conteúdo abordado"

Neste trabalho testamos a hipótese de que modelos tridimensionais de diversos tipos celulares, assim como de processo envolvendo células (multiplicação celular e a cicatrização), utilizados inicialmente de forma tátil, pode ser uma ferramenta eficiente para o ensino de biologia celular em uma perspectiva de inclusão de alunos com NEE.

Um aspecto dos nossos resultados que chama a atenção é o fato de que a atividade não mudou, nos alunos, a representação da célula como "ovo frito". Esta representação foi de $59 \%$ no pré-teste e de $61 \%$ no pós-teste. Clément (2007) descreve que a forma celular "ovo-frito" é um modelo de fácil compreensão e descrição. Já Gama (2012) salienta que ao desenharem a forma "ovo frito", fica evidente a falta de habilidade para representar essa complexa e diversa estrutura que é a célula. Devemos lembrar também que esta representação é uma simplificação utilizada como uma das primeiras apresentações de célula nos livros didáticos e também em aula pelos professores.

Os nossos modelos didáticos priorizaram as diferentes formas celulares e não as estruturas subcelulares, assim, não poderíamos esperar que houvesse uma mudança na repressão das células, do modelo "membrana-citoplasma-núcleo" para um modelo representado com várias organelas.

Como salientado anteriormente, os nossos modelos trataram da diversidade dos tipos celulares e de processos biológicos básicos, como crescimento e cicatrização. Nestes aspectos, os modelos mostram-se como de significativo auxílio pedagógico. Mesmo já tendo estudado os conteúdos envolvendo "célula", 31\% dos alunos manifestaram entendimento de que todas as células eram iguais e similares às representadas no "modelo ovo frito". Após as atividades apenas $4 \%$ ainda mantiveram este entendimento. Assim, mesmo que tenham continuado desenhando a célula como "ovo frito", parte 
destes alunos manifestou entendimento de que as células podem apresentar diferentes formatos. No pós-teste, $14 \%$ dos alunos desenharam células com outros formatos (células nervosas e musculares).

Outro aspecto a salientar é que o entendimento de processos biológicos básicos, como crescimento e cicatrização, teve uma significativa melhora com o uso dos modelos. No pré-teste $35 \%$ dos alunos desconheciam a relação das células com o crescimento e $25 \%$ com o envolvimento delas com a cicatrização. Após a atividade praticamente todos os alunos conseguiram relacionar corretamente o papel das células nesses processos.

Carlan et al. (2014) sugerem que, no Ensino Fundamental, a ênfase sobre ensino de biologia celular deve ser dada aos conceitos mais básicos, como a célula como unidade de composição dos seres vivos, sua dimensão, as diferentes formas que pode possuir, assim como seu papel nos processos biológicos básicos, como o crescimento, reprodução e cicatrização. Nestes aspectos, os modelos utilizados neste artigo, empregando um primeiro momento de interação "tátil", mostraram-se úteis para o ensino-aprendizagem desses conceitos básicos.

Outro ponto a ser salientado é que a metodologia aqui proposta retira o aluno da passividade. A utilização dos modelos didáticos na atividade de percepção tátil e seu uso durante a abordagem dos conceitos de crescimento humano/multiplicação celular e cicatrização da pele, permitiram aos alunos tornarem-se ativos durante o processo de aprendizagem, manuseando, tocando, observando, questionando, construindo e desconstruindo conceitos já preestabelecidos. Percebemos que ao final das atividades os alunos conseguiram elaborar respostas claras e sucintas ao serem questionados sobre as temáticas.

Por meio da atividade de percepção tátil realizada foi possível proporcionar a integração dos alunos e, ao mesmo tempo, propiciar aos alunos videntes aguçarem a sua percepção tátil que habitualmente não é utilizada, de modo que perceberam como é um dos meios usados por seus colegas deficientes visuais, interagindo com o meio ambiente para obter informações.

A atividade de percepção tátil realizada com as turmas possibilitou aos educandos aprenderem sobre célula de uma maneira diferente da que estavam acostumados, tornando o ensino e o aprendizado interessante e motivador, como podemos perceber na fala do aluno 1: "No meu ponto de vista foi legal, porque a gente aprendeu, viveu como que a ' $V$ ' sente. Porque como ela não enxerga, só pelo tato dela, aí um pouco foi por causa disso a turma toda achou legal, até foi um jeito novo de estudar, que a gente nunca tinha feito, bem legal (A1)".

Os trabalhos de Santos e Manga (2009), Wallach et al. (2016) e Pietricoski e Menin (2015) concluem que a utilização de modelos didáticos no ensino de Ciências, dos Ensinos Fundamental e Médio, com enfoque principalmente em temáticas que envolvem o ensino de célula, propiciam uma melhor aprendizagem, assimilação e compreensão aos alunos com e sem deficiência visual. 
Lima, Amorin e Luz (2018, p. 44), ao questionarem estudantes do 10 ano do Ensino Médio de uma escola pública do Estado do Pará, verificaram que 46,15\% dos entrevistados alegaram que "o conteúdo célula é o mais difícil de compreender". Essa dificuldade é evidenciada diariamente nas salas de aula da Educação Básica. Assim, faz-se necessário, e de grande importância, a utilização de metodologias que facilitem a compreensão e assimilação destas temáticas com alto nível de abstração, e que proporcionem a vinculação do conteúdo teórico com o cotidiano do estudante, para assim efetivar o processo de aprendizagem dos estudantes (POSSOBOM; OKADA; DINIZ, 2003)

Durante as entrevistas orais realizadas cinco meses após a atividade, foi possível perceber, nos comentários dos alunos, que eles guardam os modelos das células trabalhadas na atividade em suas mentes, embora pouquíssimos lembrassem os nomes das estruturas trabalhadas na atividade. Salientamos que o aluno, ao entrar em contato com os modelos didáticos, tem maior facilidade na percepção das diferentes formas, ajudando-o a reconstruir seu conceito referente aos formatos celulares existentes.

[...] é importante realizar atividades experimentais para favorecer a aprendizagem de conceitos científicos. Se ela é importante para alguns alunos, certamente também é importante para os alunos com deficiência visual. Desta forma, para que não ocorra exclusão, ela deverá ser pensada para todos os alunos. Ou seja, necessitamos criar alternativas que tornem o nível macroscópico acessível aos estudantes com deficiência visual (RAPOSO; MÓL, 2010, p. 299).

Visto que todos os alunos têm a capacidade de aprender, eles só necessitam ser estimulados de forma que facilite a sua compreensão sobre o assunto. Costa et al. (2011, p. 11), argumentam que os "alunos com deficiência visual podem aprender (...) tão bem quanto os alunos videntes, bastando que para isso sejam fornecidas ferramentas adequadas para tal". Nesse sentido, Góes (2002) e Bazon (2012) defendem que práticas devam ser realizadas igualmente para todos os alunos, fazendo-se necessárias práticas inclusivas, com meios alternativos e uso de recursos especiais.

Outro fato relevante da atividade aqui descrita é que os alunos tiveram uma maior compreensão sobre os processos de crescimento humano e cicatrização da pele. Eles perceberam que as células estão presentes em ambos os processos, como podemos ver na fala: - "vai lá, ela fecha, daí depois, daí cria a casquinha, vai se criando novas células... a gente vai crescendo, aumenta o número de células, elas se multiplicam".

Foi notável, durante a entrevista, que os alunos não recordavam os nomes e as funções específicas de todas as células, mas lembravam das etapas básicas dos processos trabalhados, embora de forma muito simples, e conseguiram contextualizar a participação das células nestes processos. Carlan et al. (2014) reforçam que se deve trabalhar conceitos básicos de biologia celular, como multiplicação celular, cicatrização da pele e crescimento humano, com alunos do Ensino Fundamental, visto que essas temáticas são pouco abordadas e os alunos apresentaram grande curiosidade e expressivo entusiasmo, tornando-se mais efetivo do que trabalhar estruturas subcelulares, dado que essa temática é mais indicada para ser trabalhada no Ensino Médio. 
A integração entre os alunos com deficiência visual e os alunos videntes com práticas não segregacionistas, que busca a inclusão dos alunos independentemente de sua limitação, só traz benefícios aos estudantes no ambiente escolar e fora dele. $\mathrm{Na}$ fala do aluno percebemos a importância de atividades inclusivas:

Eu acho que ajudou (...) também acredito que parte da turma não sabia muito bem disso e vai ser bom para ' $N$ ' também sobre aquilo de tocar envolve a turma, e a ' $N$ ' e ' $F$ ' envolve eles dois, e é um trabalho em grupo que vai ajudar a gente a entender eles, ah como eles sentem por só tocar nas coisas e não ver e é mais alguma coisa que junta nós todos não deixa a gente tão separado porque a gente é muito separado deles, eu particularmente não sou da ' $N$ ', mas do ' $F$ ' eu sou, porque não tenho tanta amizade assim com ele mas eu acho que é uma coisa que vai unir todo mundo eu acho bem interessante bem legal (A8) (fala de um aluno a respeito da atividade realizada com a turma).

Por meio deste sucinto relato percebemos que os alunos passam a perceber e conhecer as limitações dos seus colegas, que são impostas pela deficiência, mas ao mesmo tempo percebem que eles conseguem realizar todas as atividades propostas à turma mediante algumas adaptações. Observamos também que todos têm sua singularidade e sua individualidade, que todos nós somos diferentes, notamos que os colegas têm capacidade para aprender e participar do convívio escolar.

"A busca por uma didática inclusiva não é simples, deve respeitar e superar os modelos pedagógicos gerais, enfatizando o impacto das variáveis específicas na implantação de uma educação para todos" (CAMARGO, 2010, p. 260). Com práticas inclusivas, estaremos formando cidadãos preocupados com os outros, mais tolerantes, sem preconceitos.

\section{CONCLUSÃO}

A utilização de modelos didáticos construídos de forma que possam ser observados não apenas visualmente, mas também de forma tátil, contribui para a inclusão de alunos com deficiência visual na classe regular de ensino. Proporcionam tanto ao aluno sem limitação visual como àquele com deficiência visual poder "ver" estruturas microscópicas de forma ampliada, compreender essas estruturas e possibilitar a sua imaginação por meio do ver visual ou do "ver" através do tato.

Podemos observar que, em um primeiro momento, os alunos videntes e com deficiência visual tiveram dificuldade em responder sobre conceito/imagem de células, formatos das células, crescimento humano e processo de cicatrização. Também foi perceptível que os alunos videntes e os com deficiência visual não são incentivados a utilizar o sentido do tato para conhecer estruturas e/ou objetos em 3D durante as aulas de Ciências.

Após a intervenção e a apresentação aos alunos dos modelos didáticos celulares e a conversa com a turma sobre as funções e processos dos conceitos trabalhados, os participantes, ao serem questionados novamente, apresentaram as suas respostas mais curtas e objetivas, demonstrando que, de forma muito simples, entenderam como decorriam tais processos de multiplicação celular e cicatrização da pele. 
Outro ponto da atividade foi que os alunos videntes puderam utilizar outro sentido, o tato, além da visão, para, em um primeiro momento, "ver" os modelos didáticos celulares. Esses alunos vivenciaram um pouquinho das dificuldades encontradas no dia a dia de seus colegas cegos. Mesmo diante das dificuldades encontradas por eles, ficaram bastante empolgados com a atividade. Os alunos videntes e com deficiência visual tornaram-se mais ativos durante a atividade, interagindo com os colegas e com o conteúdo que estavam aprendendo.

\section{REFERÊNCIAS}

AREND, Felipe Lohmann; DEL PINO José Claudio. Uso de questionário no processo de ensino e aprendizagem em biologia. Revista de Ensino de Biologia, v. 10, n. 1, p. 72-86, 2017. ISSN: 1982-1867. Disponível em: http://sbenbio.journals.com.br/index.php/sbenbio/article/view/36/6. Acesso em: 23 dez. 2018.

BAZON, Fernanda Vilhena Mafra. Escolarização de alunos com deficiência visual: elaboração e utilização de materiais didáticos como recursos pedagógicos inclusivos. In: ENCONTRO NACIONAL DE DIDÁTICA E PRÁTICAS DE ENSINO, 16., 2012, Campinas. Anais eletrônicos [...]. Campinas: Unicamp, 2012, p. 13-24. Disponível em: http://www.infoteca.inf.br/endipe/smarty/templates/arquivos_template/upload_arquivos/acervo/docs/2489c.pdf. Acesso em: 15 jan. 2019.

CAIADO, Kátia Regina Moreno. Aluno com deficiência visual na escola: lembranças e depoimentos. 3. ed. Campinas, SP: Autores Associados, 2014. p. 1-148.

CAMARGO, Eder Pires de. A comunicação como barreira à inclusão de alunos com deficiência visual em aulas de mecânica. Ciência \& Educação, v. 16, n. 1, p. 259-275, 2010. Disponível em: http://www.scielo. $\mathrm{br} / \mathrm{pdf} / \mathrm{ciedu} / \mathrm{v} 16 \mathrm{n} 1 / \mathrm{v} 16 \mathrm{n} 1 \mathrm{a} 15$. Acesso em: 11 jan. 2019.

CAMARGO, Eder Pires de. Inclusão e necessidade educacional especial: compreendendo identidade e diferença por meio do ensino de física e da deficiência visual. São Paulo: Livraria da Física, 2016. p. 268.

CARLAN, Franciele Abreu et al. Teaching Cell Biology in Primary Schools. Education Research International, p. 1-5, 2014. Disponível em: https://www.hindawi.com/journals/edri/2014/272475/ref/. Acesso em: 26 dez. 2018.

CAVALCANTE, Dannuza Dias; SILVA, Aparecida de Fátima Andrade da. Modelos didáticos e professores: concepções de ensino-aprendizagem e experimentações. In: ENCONTRO NACIONAL DE ENSINO DE QUÍMICA, 14., 2008. Curitiba. Anais Eletrônicos... Curitiba: ENEQ; UFPR, 2008. Disponível em: http://www. quimica.ufpr.br/eduquim/eneq2008/resumos/R0519-1.pdf. Acesso em: 24 dez. 2018.

CLÉMENT, Pierre. Introducing the Cell Concept with both Animal and Plant Cells: A Historical and Didactic Approach. Science \& Education, v. 16, p. 423-440, mar. 2007.

COIMBRA, Ivanê Dantas. Inclusão do portador de deficiência visual na escola regular. Salvador: Edufba, 2003. 240p.grafia?

COSTA, Jhonatha Junio Lopes et al. Ensino de física para deficientes visuais: métodos e materiais utilizados na mudança de referencial observacional. In: ENCONTRO NACIONAL DE PESQUISA EM EDUCAÇÃO EM CIÊNCIAS (ENPEC), 8., 2011, Campinas. Anais eletrônicos [...]. Campinas: Enpec, 2011. p. 1-12. Disponível em: http://www.nutes.ufrj.br/abrapec/viiienpec/resumos/R0086-2.pdf. Acesso em: 30 dez. 2018.

GAMA, A. F. A célula no divã: representações de imagens de células entre estudantes do Ensino Médio a partir de uma perspectiva cultural. 2012, 157f. Dissertação (Mestrado em Educação em Ciências e em Matemática) - Universidade Federal do Paraná, Curitiba, PR, 2012. Disponível em: http://acervodigital. ufpr.br/bitstream/handle/1884/28694/R\%20-\%20D\%20-\%20ADRIANA\%20FERREIRA\%20GAMA.pdf?sequence=1\&isAllowed=y. Acesso em: 13 jan. 2019.

GIORDAN, A.; VECCHI, G. Do saber: das concepções dos aprendentes aos conceitos científicos. 2. ed. Porto Alegre: Artmed, 1996. p. 222. Disponível em: https://edisciplinas.usp.br/pluginfile.php/171160/mod_ resource/content/2/Giordan\%20e\%20de\%20Vecchi\%20parte\%201.PDF. Acesso em: 12 dez. 2018.

GÓES, M. C. R. Relações entre desenvolvimento humano, deficiência e educação: contribuições da abordagem histórico-cultural. In: OLIVEIRA, M. K.; SOUZA, D. T. R.; REGO, T. C. Psicologia, educação e as temáticas da vida contemporânea. São Paulo: Moderna, 2002. p. 95-114.

JUSTINA, Lourdes Aparecida Della et al. Modelos didáticos no ensino de genética. In: SEMINÁRIO DE EXTENSÃO UNIVERSITÁRIA DA UNIOESTE, 3., 2003, Cascavel-PR. Anais [...]. Cascavel-PR, 2003. p. 135-140.

MOTTER, Rose Maria Bellim; LISBÔA, Erosan la (org.). Cascavel: Edunioeste, 2003. 775 p. 
LIMA, Josiane Ferreira de; AMORIM, Thamiris Vasconcelos; LUZ, Priscyla Cristinny Santiago da. Aulas práticas para o ensino de Biologia: contribuições e limitações no Ensino Médio. Revista de Ensino de Biologia, v. 11 , n. 1, p. 36-54, 2018. ISSN: 1982-1867. Disponível em:http://sbenbio.journals.com.br/index.php/ sbenbio/article/view/107/24. Acesso em: 2 jan. 2019.

LIPPE, Eliza Marcia Oliveira; CAMARGO, Éder Pires de. Ensino de ciências e deficiência visual: discursos e práticas inclusivas para a formação de professores. In: Ensino de Ciências e inclusão escolar: investigações sobre o ensino e a aprendizagem de estudantes com deficiência visual e estudantes surdos. Curitiba, PR: CRV, 2016. p. 232.

MATOS, Cysneiros et al. Utilização de modelos didáticos no ensino de entomologia. Revista de Biologia e Ciências da Terra, v. 9, n. 1, p. 19-23, 2009. Disponível em: http://www.redalyc.org/pdf/500/50016921003. pdf. Acesso em: 22 dez. 2018.

NERY, F. C.; RODRIGUEZ, M. B. Modelos didáticos em genética: uma abordagem concreta. São Paulo: Loyola, 1998.

ORLANDO, Tereza Cristina et al. Planejamento, montagem e aplicação de modelos didáticos para abordagem de biologia celular e molecular no ensino médio por graduandos de ciências biológicas. Revista Brasileira de Ensino de Bioquímica e Biologia Molecular, n. 1, p. 17, 2009. ISSN: 1677-2318. Disponível em: http://www.educadores.diaadia.pr.gov.br/arquivos/File/2010/artigos_teses/Biologia/Artigos/modelos_didaticos.pdf. Acesso em: 22 dez. 2018.

PAULA, Tatiane Estácio de; GUIMARÃES, Orliney Maciel; SILVA, Camila Silveira da. Necessidades formativas de professores de química para a inclusão de alunos com deficiência visual. Revista Brasileira de Pesquisa em Educação em Ciências, v. 17, n. 3, p. 853-881, 2017. ISSN: 1984-2686. Disponível em: https:// seer.ufmg.br/index.php/rbpec/article/view/3519/7930. Acesso em: 3 jan. 2019.

PIETRICOSKI, Luciana Borowski; MENIN, Martha. A inclusão de alunos portadores de deficiências visuais no ensino de ciências e biologia: confecção de modelos didáticos para o ensino de citologia. In: CONGRESSO INTERNACIONAL DE TECNOLOGIA NA EDUCAÇÃO, 13., 2015, Pernambuco. Anais [...]. Pernambuco: Senac, 2015. p. 1-10. Disponível em: <http://www.pe.senac.br/congresso/anais/2015/arquivos/pdf/ poster/A\%20INCLUS\%C3\%830\%20DE\%20ALUNOS\%20PORTADORES\%20DE\%20DEFICI\%C3\%8ANCIAS\%20 VISUAIS\%20NO\%20Confec\%C3\%A7\%C3\%A30\%20de\%20modelos\%20did\%C3\%A1ticos\%20para\%20o\%20 ensino\%20de\%20Citologia.pdf>. Acesso em: 15 jan. 2019.

POSSOBOM, Clívia Carolina Fiorilo; OKADA, Fatima Kazue; DINIZ, Renato Eugênio da Silva. Atividades práticas de laboratório no ensino de biologia e de ciências: relato de uma experiência. In: GARCIA, Wilson Galhego; GUEDES, Alvaro Martim (org.). Núcleos de ensino. São Paulo, 2003. p. 113- 123. V. 1.

RAPOSO, P. N.; MÓL, G. S. A diversidade para aprender conceitos científicos: a ressignificação do ensino de Ciência a partir do trabalho pedagógico com alunos cegos. In: SANTOS, W. L. P.; MALDANER, O. A. (org.). Ensino de química em foco. ljuí: Ed. Unijuí, 2010. 368p.

REIS, I. A. et al. O ensino de biologia sob uma perspectiva CTSA: análise de uma proposta pedagógica de uso de modelos didáticos da divisão celular. In: ENCONTRO NACIONAL DE PESQUISA EM ENSINO DE CIÊNCIAS, 9., 2013, Águas de Lindoia. Anais [...] Águas de Lindóia: Enpec, 2013.

SANTOS, Camila Reis dos; MANGA, Vanessa Pita Barreira Burgos. Deficiência visual e ensino de biologia: pressupostos inclusivos. Revista FACEVV, n. 3, p. 13-22, 2009. Disponível em: https://docplayer.com.br/ 6331596-Deficiencia-visual-e-ensino-de-biologia-pressupostos-inclusivos1.html. Acesso em: 14 jan. 2019. SILVA, Tatiane Santos; LANDIM, Myrna Friederichs; SOUZA, Verônica dos Reis Mariano. A utilização de recursos didáticos no processo de ensino e aprendizagem de ciências de alunos com deficiência visual. Revista Electrónica de Enseñanza de las Ciências, v. 13, n. 1, p. 32-47, 2014.

VITALIANO, C. R. V.; MANZINI, E. J. A formação inicial de professores para a inclusão de alunos com necessidades educacionais especiais. In: VITALIANO, C. R. Formação de professor para a inclusão de alunos com necessidades educacionais especiais. Eduel: Londrina, 2010, p. 50-112.

WALLACH, Rayssa Marques et al. Utilização de modelos táteis no ensino de citologia com estudantes do instituto dos cegos Adalgisa Cunha - PB. In: CINTEDI - CONGRESSO INTERNACIONAL DE EDUCAÇÃO INCLUSIVA, 2., JORNADA CHILENA BRASILEIRA DE EDUCAÇÃO INCLUSIVA, 2., 2016, Campina Grande, PB. Anais [...]. Campina Grande, PB, 2016, p. 1-6. Disponível em: http://www.editorarealize.com.br/revistas/cintedi/trabalhos/TRABALHO_EV060_MD4_SA16_ID2316_01092016222406.pdf. Acesso em: 15 jan. 2019. 